Enes Osmančevićl,

Mirza Mehmedovićn

UDK: $316.77: 004.738 .5] 327$ (497.6)

\title{
MOGUĆNOSTI BOSANSKOHERCEGOVAČKIH ONLINE MEDIJA U INFORMIRANJU I EDUKACIJI O EUROATLANTSKIM INTEGRACIJAMA
}

\section{- Sažetak -}

Aktuelni političko-ekonomski odnosi u bosanskohercegovačkoj društvenoj stvarnosti podrazumijevaju specifičan pristup izvještavanju o procesu pristupanja Bosne i Hercegovine euroatlantskim integracijama, prvenstveno Europskoj uniji i NATO-u, kao specifičnim okvirima koji definišu aktuelnu bosanskohercegovačku međunarodnu politiku. Definirani unutrašnjim političkim sukobima, ali i predstojećim općim izborima, procesi koji su dio međunarodne politike u procesu pristupanja euroatlantskim integracijama predstavljaju poseban predmet interesovanja domaćih kako tradicionalnih tako $i$ novih (online) medija. Ovaj rad se prvenstveno bavi određenim segmentima medijskih izvještaja na online medijima kroz analizu ispunjavanja osnovnih profesionalnih novinarskih standarda, ali i specifičnih novomedijskih karakterstika koje se vežu isključivo za online medije, njihovu sveprisutnost, multimedijalnost, brzinu, prilagodljivost, informativnost, edukativnost i interakciju sa online publikom. Bitno je naglasiti da se prilikom tumačenja određenih rezultata istraživanja uzimao u obzir nivo razvijenosti online medija u Bosni i Hercegovini, njihovih ljudskih i tehničkih resursa, kultura online komuniciranja bosanskohercegovačke publike, ali i ukupna aktuelna komunikacijska situacija u Bosni i Hercegovini.

Ključne riječi: online, mediji, medijska pismenost, samoobrazovanje, Bosna i Hercegovina, NATO, Europska unija, integracija.

1 Dr. sc. Enes Osmančević, doktor komunikoloških nauka na Odsjeku za žurnalistiku Filozofskog fakulteta Univerziteta u Tuzli. E mail: enesosmancevic@yahoo.com.

2 Mr. sc. Mirza Mehmedović, viši asistent na Odsjeku za žurnalistiku Filozofskog fakulteta Univerziteta u Tuzli. E-mail: mirza.mehmedovic@ untz.ba. 


\section{Uvod}

Informativna i edukativna funkcija medija u procesu obrazovanja odraslih i političke socijalizacije posebno su značajne u online medijima, koji sve više preuzimaju ne samo publiku već i uloge i funkcije tradicionalnih medija. Pomjeranje publike od tradicionalnih ka online medijima donijelo je novi kvalitet - provjerljivost informacija. No, online mediji ne koriste prednosti weba u publiciranju informativnih i edukativnih sadržaja, čak i o važnim političkim pitanjima kakvo je pitanje pridruživanja Bosne i Hercegovine Europskoj uniji i NATO-u.

Istraživanjem mogućnosti bosanskohercegovačkih online medija u informiranju i edukaciji o euroatlantskim integracijama obuhvaćene su sljedeće web-stranice/portali:

- www.oslobodjenje.ba (Dnevni list „Oslobođenje”)

- www.avaz.ba (Dnevni list „Dnevni avaz”)

- www.nezavisne.com (Dnevni list „Nezavisne novine”)

- www.federalna.ba (Televizija Federacije Bosne i Hercegovine)

- www.depo.ba (samostalni portal)

- www.source.ba (samostalni portal)

- www.klix.ba (samostalni portal)

- www.rtrs.tv (Radio-televizija Republike Srpske)

- www.bhrt.ba (Radio-televizija Bosne i Hercegovine)

- www.rtvtk.ba (Radio-televizija Tuzlanskog kantona)

- www.slobodna-bosna.ba (Sedmični list „Slobodna Bosna”)

- www.radiosarajevo.ba (Radio Sarajevo) i

- www.6yka.com (online magazin).

Kao što je vidljivo iz liste istraživanih medija, analizirana su online izdanja tradicionalnih medija (štampe, radija i televizije), ali i samostalnih internetskih portala, koji svojom brojnošću i rasprostranjenošću u posljednjih nekoliko godina postaju sve uticajniji izvor informacija za publiku/korisnike u Bosni i Hercegovini.

U okviru kvalitativnog/sadržajnog i kvantitativnog istraživanja analizirano je ukupno jedanaest parametara po kojima su praćeni izvještaji o euroatlantskim integracijama na online medijima u Bosni i Hercegovini u periodu od 1. marta do 30. aprila 2014. godine:

- Položaj teksta na web-portalu

- Obim teksta

- Novinski žanr 
- Opremljenost teksta fotografijama

- Sadržaj fotografija

- Izvor/porijeklo teksta

- Orijentacija/pristranost medija

- Hiperlinkovi u tekstovima

- Interaktivnost teksta

- Originalnost sadržaja i

- Edukacijski sadržaji.

Kada govorimo o navedenim parametrima, bitno je naglasiti da je svaki praćen s po nekoliko pripadajućih varijabli odnosno različitih mogućnosti po kojima se mogla definisati vizualna, profesionalna i kadrovska perspektiva medija, odnosno mogućnost da profesionalno odgovori svim zahtjevima potpunog izvještavanja o aktuelnim društvenim pitanjima u Bosni i Hercegovini. Takođe, istraživanje je pokazalo znatne razlike u brzini i posvećenosti određenim temama između online izdanja tradicionalnih medija i samostalnih online portala, koji puno brže i dinamičnije odgovaraju zahtjevima publike, s obzirom da je za njih internet, odnosno interkacija sa publikom, jedini način za pozicioniranje na medijskom tržištu. S druge strane, bitan okvir koji utiče na kvalitet online komuniciranja sa publikom jeste posvećenost urednika i novinara na online medijima procesu edukacije publike, kako o aktuelnim društvenim pitanjima tako i o samom načinu korištenja savremenih kanala komuniciranja. Kada govorimo o konkretnoj temi, odnosno euroatlantskim integracijama, i njenoj zastupljenosti u online medijima, izuzetno je razočaravajući podatak da tokom perioda istraživanja nije zabilježen niti jedan slučaj edukativnog teksta koji bi za cilj imao obrazovanje publike o euroatlantskim integracijama, osnovnim formalnim i sadržajnim elementima i političkim procesima u Bosni i Hercegovini koji spadaju u domen ispunjavanja uslova za pristupanje EU i NATO-u. Ovaj rezultat se može tumačiti kao posebno negativan u kontekstu popularnosti online medija (izdanja) i sve veće upućenosti publike na internetske portale kao primarni izvor informacija.

Iz priložene tabele, u kojoj je prikazano koliko je tekstova koji se mogu vezati za izvještavanje o euroatlantskim integracijama objavljeno na svakom mediju pojedinačno, vidljivo je da ovim temama puno više pažnje posvećuju online izdanja dnevnih listova i samostalni internetski portali nego što to čine internetska izdanja televizijskih i radijskih stanica, odnosno magazina. To se može obrazložiti aktivnijim praćenjem dnevnopolitičkih dešavanja u redakcijama dnevnih listova i informativnih portala, dok se 
online izdanja magazina, odnosno radijskih i televizijskih stanica, više bave senzacionalističkijim, spektakularnijim, zabavnijim i publici prihvatljivijim temama ili, pak, najavama određenih emisija (tema) koje će se naći u tradicionalnim izdanjima.

\section{Tabela 1: Prikaz ukupnog broja objavljenih tekstova pojedinačno po medijima}

\begin{tabular}{|l|r|}
\hline Naziv medija/web-stranice & Objavljeno tekstova \\
\hline oslobodjenje.ba & 86 \\
\hline avaz.ba & 126 \\
\hline nezavisne.com & 98 \\
\hline federalna.ba & 41 \\
\hline depo.ba & 68 \\
\hline source.ba & 79 \\
\hline klix.ba & 87 \\
\hline rtrs.tv & 41 \\
\hline bhrt.ba & 46 \\
\hline rtvtk.ba & 23 \\
\hline slobodna-bosna.ba & 28 \\
\hline radiosarajevo.ba & 37 \\
\hline 6yka.com & 12 \\
\hline \multicolumn{1}{|c|}{ Ukupno } & 772 \\
\hline
\end{tabular}

\section{Pozicioniranje tekstova}

Vizualni položaj aktuelnih informacija na online medijima uglavnom ima unificiranu formulu na svim web-stranicama koje su bile predmet istraživanja, što znači da su vijesti o euro-atlantskim integracijama, u skladu sa aktuelnošću i interesom publike, uglavnom pozicionirane na rotirajućim (reklamnim) slajdovima ili u prvoj sekciji tekstova na naslovnoj stranici. U ovisnosti o padu interesovanja publike za određeni tekst, on je pomjeran na sporedne sekcije dok ne bude u potpunosti uklonjen sa vidljivih dijelova naslovne stranice. Svi portali imaju odgovarajuće arhive u kojima je moguće pronaći svaki tekst, bez obzira na vremenski interval od objavljivanja. 


\section{Grafikon 1: Položaj teksta na stranici (procentualno)}

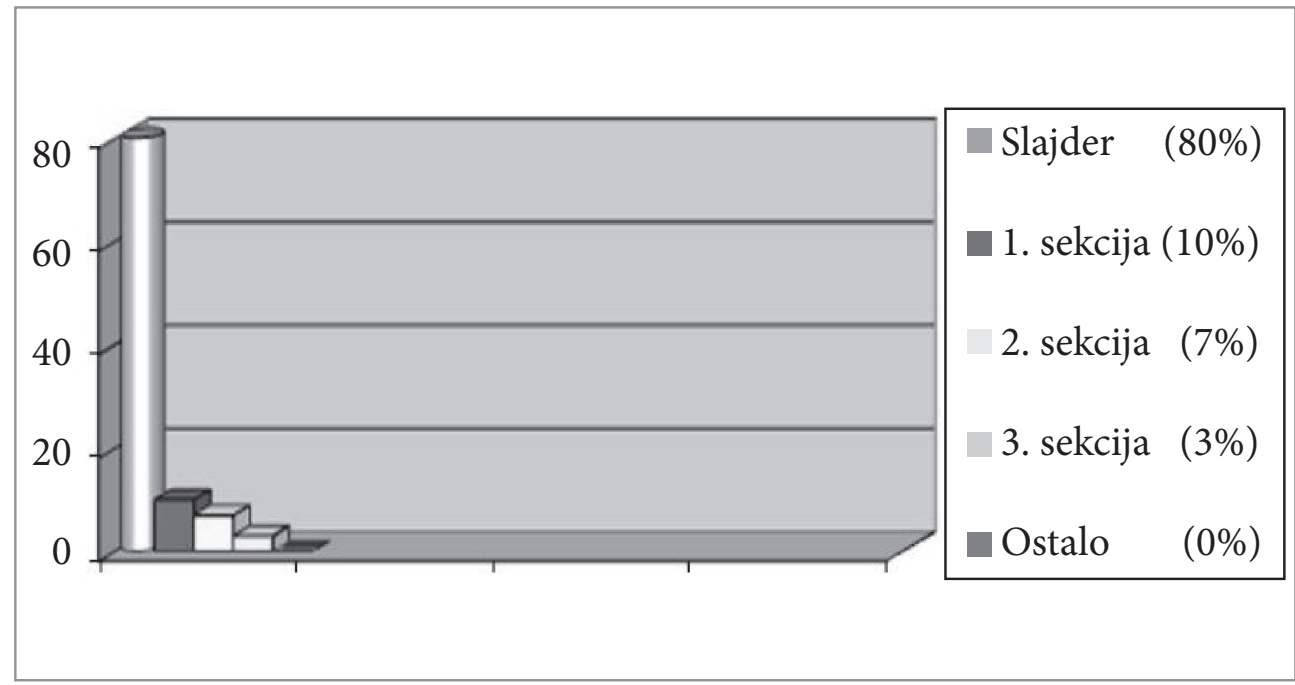

Istaknutost tekstova na stranicama može se tumačiti zainteresiranošću publike za teme koje se tiču euroatlantskih integracija, ali i uključenosti političkih partija, kao aktivnih sudionika političkih kretanja u Bosni i Hercegovini, u diskusije o uslovima i procesima koje Bosna i Hercegovina prolazi na putu ka Europskoj uniji i NATO-u. Ovo je posebno bitan faktor za vizualnu istaknutost ako znamo da su aktivnosti političkih partija i međusobni animoziteti političkih lidera u Bosni i Hercegovini najprivlačnija tema $\mathrm{u}$ izbornoj godini.

Ako govorimo o pojedinačnim primjerima vizualnog isticanja tekstova koji se tiču euro-atlantskih integracija, možemo reći da su najviše pažnje vizualnom prikazu posvetili samostalni internetski portali (klix.ba i source.ba), koji su najveći procenat svojih tekstova pozicionirali na udarnim slajdovima.

Tabela 2: Mediji sa najvećim procentom istaknutih tekstova na rotirajućim slajdovima

\begin{tabular}{|c|c|c|}
\hline Medij & Ukupno tekstova & Slajder \\
\hline klix.ba & 87 & 76 \\
\hline source.ba & 79 & 70 \\
\hline
\end{tabular}




\section{Obim tekstova}

S obzirom da su predmet analize bili online mediji, koji u svojim teorijskim temeljima podrazumijevaju brži i sažetiji oblik komunikacije s publikom u odnosu na tradicionalne medije, razumljivo je zašto su rezultati istraživanja pokazali da su se autori/urednici uglavnom odlučivali za kratke novinske forme (vijesti i izvještaje), obima do 20 redova, dok su rijetki primjeri širih analitičkih tekstova obimnijih od 30 redova. Obimniji tekstovi su uglavnom zabilježeni u slučajevima kada su teme izvještaja zahtijevale šire analize i uključivanje većeg broja izvora a ovakvi izvještaji su uglavnom primijećeni na online izdanjima dnevnih listova te sedmičnog magazina Slobodna Bosna, koji u praksi nudi obimnije tekstove, kako u tradicionalnom tako i u online izdanju.

Ako uzmemo u obzir pozicioniranost i obim tekstova koji su se ticali euroatlantskih integracija, možemo izvesti zaključak da se online mediji uglavnom uklapaju u karakterističan okvir savremene javne komunikacije $\mathrm{u}$ Bosni i Hercegovini, posebno one koja važi za tradicionalne medije, a koja gaji praksu senzacionalističkog izvještavanja, kombinovanog sa zabavljačkim predstavljanjem ključnih činjenica, uklopljenim u važeća očekivanja publike u Bosni i Hercegovini.

\section{Grafikon 2: Obim tekstova (izražen procentualno)}

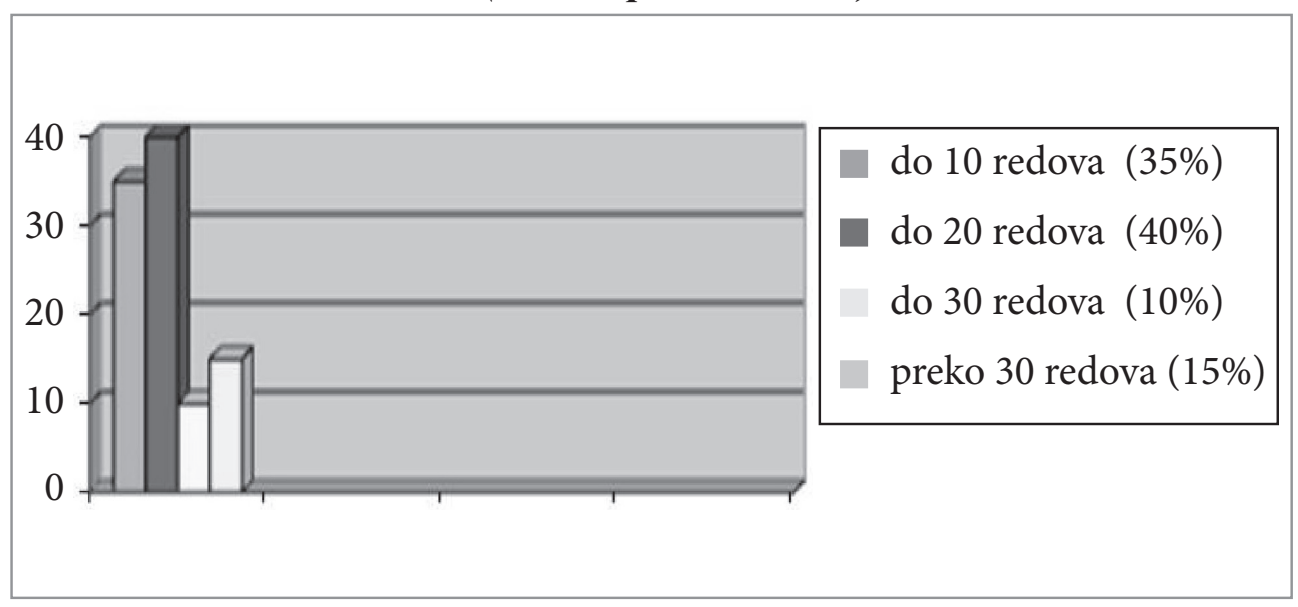


Kada govorimo o procentualnom udjelu obimnijih izvještaja u odnosu na ukupan broj objavljenih tekstova o euroatlantskim integracijama, kao što je već navedeno, obimniji tekstovi su uglavnom evidentirani u online izdanjima dnevnih listova Oslobođenje, Dnevni avaz i Nezavisne novine te sedmičnog magazina Slobodna Bosna, dok je takođe isti slučaj primijećen u sadržajima online magazina 6yka.com, online medija koji posebnu pažnju posvećuje analizama i opširnijim izvještajima o aktuelnim društvenim temama.

\section{Tabela 3: Prikaz medija koji su imali najveći udio obimnijih tekstova (preko 30 redaka)}

\begin{tabular}{|c|c|c|}
\hline Medij & Ukupno tekstova & Preko 30 redaka \\
\hline oslobodjenje.ba & 86 & 38 \\
\hline avaz.ba & 126 & 115 \\
\hline nezavisne.com & 98 & 75 \\
\hline slobodna-bosna.ba & 28 & 23 \\
\hline 6yka.com & 12 & 10 \\
\hline
\end{tabular}

\section{Novinski žanrovi}

Kako je navedeno u prethodnoj sekciji, online mediji u Bosni i Hercegovini, izvještavajući o aktuelnim temama iz domena euroatlantskih integracija, pribjegavaju uglavnom kraćim novinskim formama, vijestima i izvještajima, što zbog prilagođavanja specifičnim zahtjevima online publike što zbog ograničenih ljudskih i tehničkih resursa. Kada tumačimo ovu činjenicu, bitno je napomenuti da se online mediji u Bosni i Hercegovini, bez obzira o kojim predmetima izvještavanja govorimo, zadržavaju pretežno na konstatovanju društvenih pojava, odnosno aktuelnih događaja, što žanrovski spada u domen vijesti ili izvještaja. Online mediji u Bosni i Hercegovini evidentno nisu ni kadrovski ni tehnički osposobljeni za percipiranje šire slike događaja, upuštanje u analize ili kontaktiranje većeg broja izvora, zbog čega je najveći broj evidentiranih kratkih vijesti tokom analiziranog perioda (procentualno više od 40 odsto). 


\section{Grafikon 3: Novinski žanrovi (procentualni udio)}

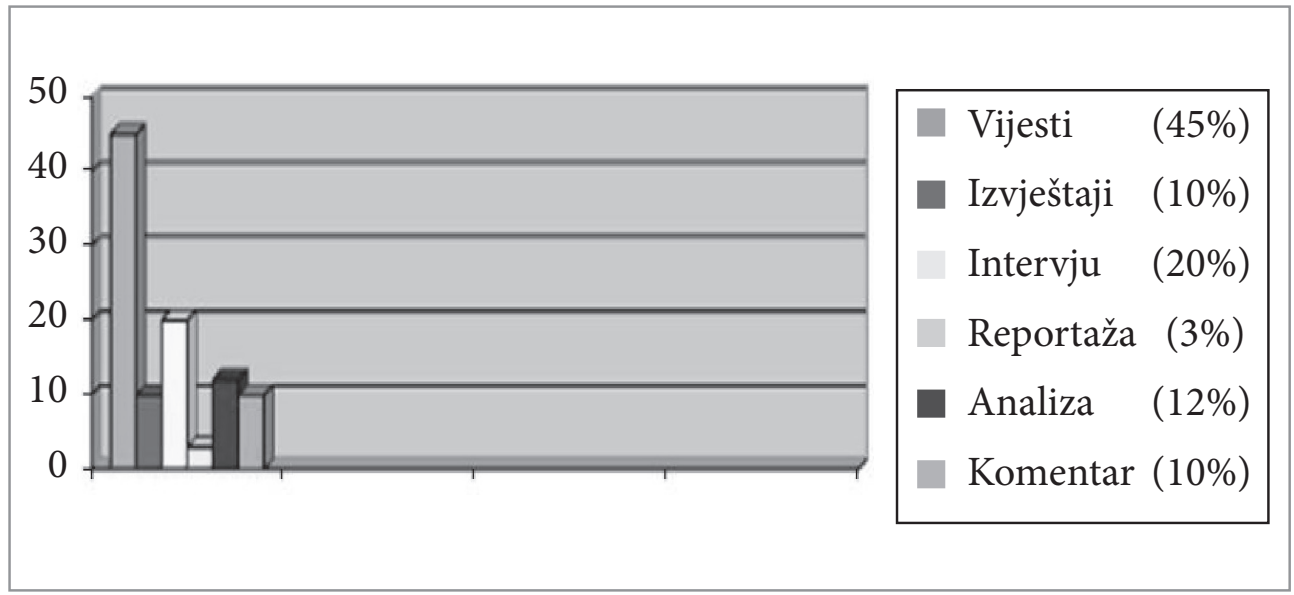

Kao što je dijelom navedeno u prethodnom poglavlju, najveći udio obimnijih tekstova su ponudila online izdanja dnevnih listova, koji su uz kvantitet ponudili i žanrovski najraznovrsnije sadržaje unutar objavljenih tekstova o euroatlantskim integracijama. Uzimajući u obzir imanentne medijske funkcije sa jedne strane, koje podrazumijevaju i edukativnu funkciju medija te žanrovsku unificiranost analiziranih tekstova, zaključuje se da online mediji u Bosni i Hercegovini kadrovski/obrazovno nisu osposobljeni da potrebe publike podignu na viši komunikacijski nivo, te da zadovoljavaju isključive elementarne potrebe korisnika za osnovnom informacijom i zabavom. To u konačnici proizvodi unificiranu publiku online medija koja ne nudi adekvatan feedback, niti traži profesionalniji pristup izvještavanju o bitnim društvenim temama.

Tabela 4: Prikaz žanrovske raznovrsnosti na izdvojenim online medijima

\begin{tabular}{|c|c|c|c|}
\hline Medij & Ukupno tekstova & \multicolumn{2}{|c|}{$\begin{array}{c}\text { Procentualni udio tekstova } \\
\text { po Žanrovima }\end{array}$} \\
\hline \multirow{6}{*}{ oslobodjenje.ba } & \multirow{6}{*}{86} & vijest & $42 \%$ \\
\hline & & izvještaj & $20 \%$ \\
\hline & & intervju & $15 \%$ \\
\hline & & reportaža & $0 \%$ \\
\hline & & analiza & $18 \%$ \\
\hline & & komentar & $5 \%$ \\
\hline
\end{tabular}




\begin{tabular}{|c|c|c|c|}
\hline \multirow{6}{*}{ avaz.ba } & \multirow{6}{*}{126} & vijest & $40 \%$ \\
\hline & & izvještaj & $26 \%$ \\
\hline & & intervju & $8 \%$ \\
\hline & & reportaža & $4 \%$ \\
\hline & & analiza & $12 \%$ \\
\hline & & komentar & $18 \%$ \\
\hline \multirow{6}{*}{ nezavisne.com } & \multirow{6}{*}{98} & vijest & $40 \%$ \\
\hline & & izvještaj & $13 \%$ \\
\hline & & intervju & $15 \%$ \\
\hline & & reportaža & $5 \%$ \\
\hline & & analiza & $18 \%$ \\
\hline & & komentar & $9 \%$ \\
\hline
\end{tabular}

\section{Opremljenost tekstova fotografijom}

Vizuelnom prikazu (multimedijalnosti), prema rezultatima istraživanja, online mediji u Bosni i Hercegovini poklanjaju polovičnu pažnju, s obzirom da u preko 40 odsto slučajeva tekstovni nisu nikako, ili su loše opremljeni fotografijama (male fotografije). Ovaj pokazatelj govori da online mediji ne raspolažu adekvatnom fotoarhivom, odnosno da ne pokrivaju događaje svojim fotoreporterima ili saradnicima, te da nisu u mogućnosti otkupiti odgovarajuća autorska prava na fotografije drugih medija. Kao dokaz tome dodatno služe i rezultati o sadržaju objavljenih fotografija, gdje se obično nalaze domaći politički lideri (u skoro 50 posto slučajeva), iako su teme objavljenih tekstova uglavnom bile izjave stranih zvaničnika, formulisane kao kritika aktuelnih političkih lidera u Bosni i Hercegovini. Ovaj podatak pokazuje nesklad između sadržaja tekstova i fotografija kojima su oni ilustrirani.

Možemo slobodno reći, na osnovu pokazanih vizualnih ilustracija objavljenih tekstova, da online mediji ne poklanjaju dovoljnu pažnju fotografijama kao izuzetno bitnom obliku vizualne online komunikacije s publikom, te da postojeće ilustracije nisu u potpunosti usklađene sa sadržajem tekstova, odnosno da ne odgovaraju profesionalnim novinskim standardima. 


\section{Grafikon 4: Sadrăaj objavljenih fotografija (procentualni udio)}

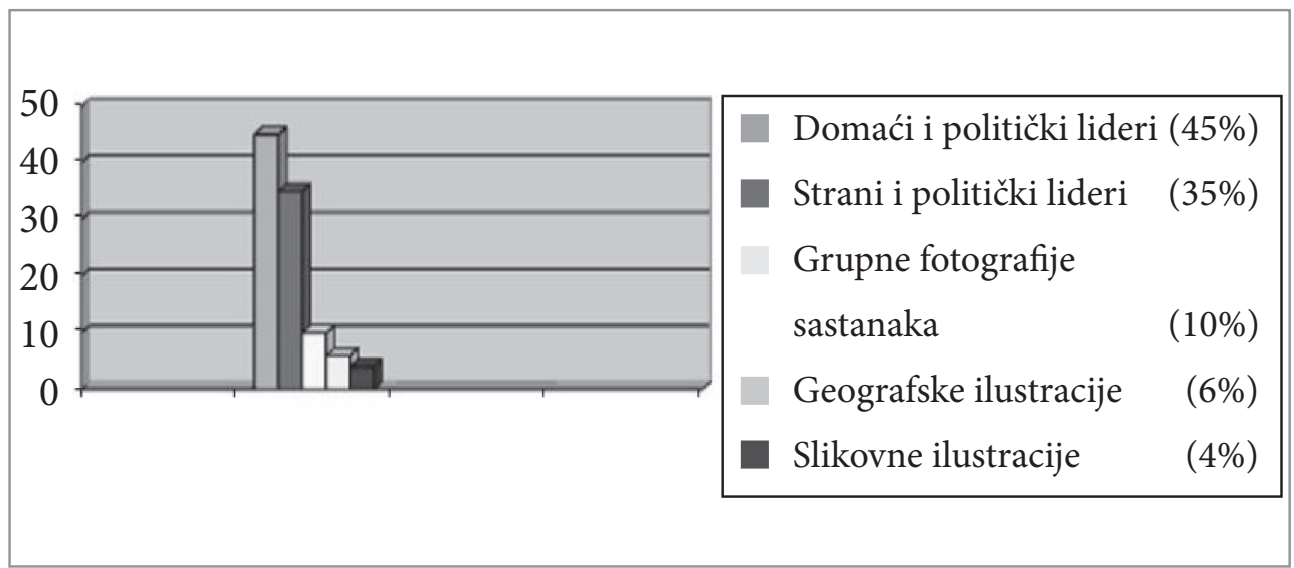

\section{Korišteni izvori u tekstovima}

Kako je dijelom navedeno u sekciji koja se tiče sadržaja objavljenih fotografija, domaći online mediji su uglavnom upućeni na strane zvaničnike kao izvore informacija, odnosno u većini objavljenih tekstova su prenesene izjave stranih političkih lidera koji su komentarisali položaj Bosne i Hercegovine $\mathrm{u}$ procesu pristupanja euroatlantskim integracijama. Istraživanje pokazuje da je u rijetkim slučajevima domaći online portal direktno stupao u kontakt sa izvorima stavova, te da su informacije uglavnom već bile objavljene na stranim medijima, te da su bosanskohercegovački mediji isključivo pravili kompilaciju već objavljenih izjava. Ovaj parametar takođe govori u prilog ranijoj konstataciji o nepoštivanju profesionalnih standarda i nemogućnosti domaćih medija da direktno stupaju u kontakt sa izvorima informacija. Kada govorimo o istraživanju korištenih izvora, uglavnom možemo konstatovati praksu copy-paste novinarstva, uz minimalne intervencije u skraćivanju jedne ili kombinaciji više različitih izjava već objavljenih na drugim medijima.

Ovo potvrđuje pretpostavku da su nosioci ukupnog funkcionisanja online medija pojedinci/urednici, ili male grupe novinara, koji nisu osposobljeni i opremljeni da direktno pokrivaju određene teme iz domena međunarodne politike. Kada govorimo o online izdanjima tradicionalnih medija, evidentirani su uglavnom istovjetni tekstovi, sa istim izvorima, koji su već objavljeni u okviru ustaljene programske šeme, bez većih intervencija i adaptacije za online publiku. 


\section{Grafikon 5: Korišteni izvori u tekstovima (procentualni udio)}

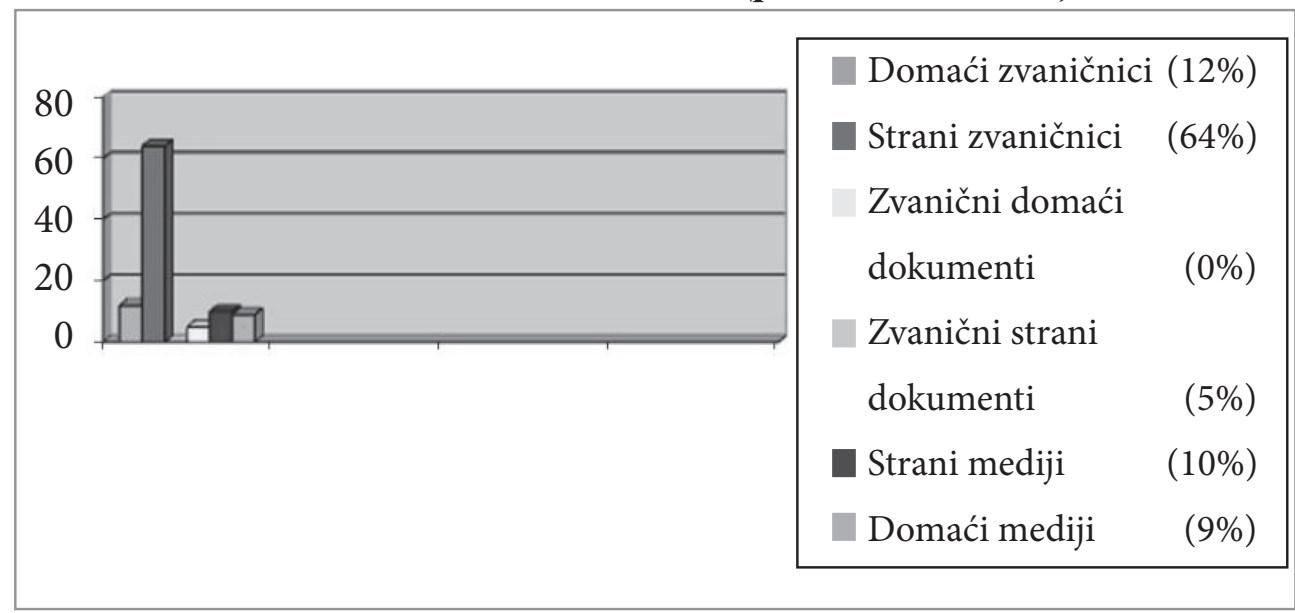

Kada govorimo o poštivanju izvora koji su korišteni u tekstovima, ili drugih medija ukoliko su tekstovi preuzeti, istraživanje pokazuje da su izvori, odnosno autori tekstova, u najvećem procentu navedeni u sadržajima online izdanja dnevnih listova, magazina Slobodna Bosna te online magazina 6yka. com. Kod navedenih medija se procenat navođenja izvora (autora, drugog medija ili agencije) kreće između 92 i 97 procenata, dok znatno niži procenat navođenja izvora evidentiramo kod samostalnih internetskih portala (klix.ba, source.ba, depo.ba), kod kojih se on kreće između 65 i 78 procenata slučajeva u kojima je naveden izvor.

\section{Orijentacija (pristranost) medija i originalnost sadržaja}

U kontekstu upućenosti online medija u Bosni i Hercegovini na druge medije i strane zvaničnike kao osnovni izvor informacija, evidentirano je da domaći mediji uglavnom zadržavaju neutralan stav o temama koje se tiču euroatlantskih integracija, te se prvenstveno zadržavaju na prenošenju već objavljenih vijesti i izvještaja. Ako uzmemo u obzir aktuelnu komunikacijsku situaciju, kao i kulturološki kontekst koji definira rad online medija u Bosni i Hercegovini, te posebno komunikacijsku osposobljenost za rad u novim uslovima medijskog tržišta, neutralan stav možemo tumačiti nespremnošću domaćih online medija za analitički/istraživački pristup izvještavanju o međunarodnim političkim pitanjima.

U čak 75 procenata objavljenih tekstova, sadržaji koji su objavljeni na domaćim online medijima su preuzeti sa drugih (domaćih i stranih) medija ili su sačinjeni kao prosti zbir nekoliko vijesti sa različitih medija. Tako 
definirana komunikacija sa publikom/korisnicima ne može se okarakterisati kao zauzimanje stava (komentarisanje ili zastupanje) po pitanju određenih tema, nego je riječ o pukom informisanju publike/korisnika o osnovnim elementima aktuelnih događaja, a publici/korisnicima je prepušteno da tragaju za opširnijim informacijama, odnosno dubljem društveno-ekonomskom kontekstu kroz koji se određeni događaji mogu tumačiti.

Većinski neutralan stav o aktuelnim temama izražen u domaćim online medijima može se tumačiti i kroz proces prilagođavanja medijskom tržištu, u kojem niti jedan online medij ne želi biti zastupnik određenog političkog stava, (in)direktno vezanog za djelovanje određene političke partije pred ovogodišnje opće izbore u Bosni i Hercegovini. Ovaj komunikacijski okvir nam govori kako su online mediji, iako manje nego tradicionalni, ipak ograničeni političkim pritiscima, te strahuju od eventualnog revanšizma vladajućih političkih struktura ukoliko postanu zastupnici suprotnog političkog stava u određenim bitnim društvenim pitanjima.

\section{Interaktivnost, povezanost i edukativnost sadržaja}

Pod pojmom interaktivnosti prvenstveno podrazumijevamo otvorenost online medija za komunikaciju sa publikom putem definisanog prostora za komentare čitalaca na odgovarajući tekst. Jasno je da se u ovakvim situacijama urednici online medija dovode u poziciju da budu pozitivno ili negativno ocijenjeni od publike, te da publici omoguće prostor koji može biti zloupotrijebljen za nametanje ličnih stavova, ili čak širenja govora mržnje prema javnim ličnostima. Uprkos opasnostima koje ovaj prostor otvara, komentarisanje je imanentan oblik komunikacije online medija s publikom, koji odgovara potrebama savremenog konzumenta masmedijskih sadržaja, koji ne želi biti samo korisnik medijskog sadržaja, već i njegov koautor, odnosno učesnik javnog diskursa.

Međutim, zabrinjavajući je podatak koji govori da u 65 procenata objavljenih tekstova o euro-atlantskim integracijama (ali i ostalih sadržaja na web-portalima) nije omogućen prostor za komentare čitalaca, čime je jasno pokazano da uredništva online medija cenzurišu stavove publike o aktuelnim društvenim pitanjima. U slučajevima u kojima je omogućen prostor za komentare čitalaca, uglavnom je riječ o tehničkim dodacima koji web-portal povezuju sa društvenim mrežama, te se u komentaru otkriva porijeklo i identitet komentatora, a administratoru je omogućeno brisanje nepoželjnih komentara na objavljene tekstove. 
Iako su domaći online portali, kako smo već naveli, uglavnom upućeni na druge medije kao izvore informacija, evidentirano je izuzetno malo odgovarajućih hiperlinkovakoji bi publiku uputili na stranice sa kojih su sadržaji preuzeti, već je proces traženja dodatnih informacija uglavnom prepušten samim korisnicima, što ovisi o njihovoj osposobljenosti da pronađu izvorne tekstove ili eventualno pronađu druge tekstove koji su direktno povezani s temom. Sve navedeno govori u prilog stalnim ograničenjima s kojima se susreće publika online medija u Bosni i Hercegovini, te sa sigurnošću možemo reći da je prostor djelovanja bosanskohercegovačkih online medija potrebno značajno unaprijediti po pitanju otvorenosti i interaktivnosti s online publikom, koja je u stalnom porastu, uz porast informacijskih potreba za blagovremenim i objektivnim medijskim sadržajima. U provedenom istraživanju nije praćen broj objavljenih komentara na određenu temu/tekst, nego isključivo spremnost portala da svojim čitaocima omogući komentarisanje/ocjenu, ili u krajnjem slučaju dopunu informacija u objavljenom sadržaju.

Kada je riječ o edukativnim sadržajima u vezi s pravom i politikom Europske unije te misijom i principima NATO-a, niti jedan sadržaj nije imao edukativni karakter u analiziranim online medijima u Bosni i Hercegovini. Nijedan online medij nije iskoristio edukacijske potencijale webkomunikacije kojima bi publici/korisnicima pružio nešto više od dnevno-informativnih sadržaja.

Interakcija publike s online medijima u Bosni i Hercegovini se uglavnom zadržava na izražavanju (ne)zadovoljstva ponuđenim informacijama, ovisno da li se one uklapaju u postojeći komunikacijski okvir. U skladu s tim, možemo sa sigurnošću reći da postojeća interakcija s publikom na online medijima $u$ Bosni i Hercegovini ne nudi adekvatan prostor za kritiku društvene stvarnosti ili dopunu postojećih informacija, već isključivo odobravanje ili negiranje postojećih društvenih standarda. Ova praksa od korisnika online medija u Bosni i Hercegovini, koji bi trebali biti ravnopravni u horizontalnoj razmjeni informacija, pravi podređene konzumente online sadržaja, što je karakterstika koja se veže isključivo za publiku tradicionalnih medija. Nedovoljna interaktivnost online medija s korisnicima implicira izostanak medijskog posredovanja u socijalnoj interakciji odrasle publike, tačnije građana $\mathrm{s}$ pravom glasa koji u velikom broju apstiniraju od izbora ili tek povremeno izlaze na izbore i nedovoljno participiraju u javnoj/političkoj komunikaciji. S tim u vezi postavlja se pitanje socijalne i političke interakcije u kristalizaciji javnog mnijenja ne samo o aktualnim dnevno-političkim pitanjima već i strateškim pitanjima daljeg opredjeljenja građana Bosne i Hercegovine prema euroatlantskim integracijama. 


\section{Zaključna razmatranja}

Slaba prisutnost tema o euro-atlanskim integracijama $u$ bosanskohercegovačkim medijima stoji u obrnutoj srazmjeri u odnosu na izniman značaj teme za budućnost društva i države - Bosne i Hercegovine. Odnos informativnih spram edukativnih sadržaja također je neizbalansiran. Svi analizirani sadržaji imali su informativni, ali ne i edukativni karakter.

Najslabija prisutnost tema o euroatlantskim integracijama je na portalima koji su inačice tradicionalnih/mainstream medija - radio i TV stanica u $\mathrm{BiH}$, a najveća na online izdanjima dnevnih novina i samostalnim portalima. To se može objasniti izraženim protivničkim ili ignorantskim stavom vladajućih političkih partija i lidera spram euroatlantskih integracija, koje ne otvaraju tu vrstu tema u političkom/javnom diskursu, i utjecajem takvih politika na uređivačke politike radio i TV stanica u Bosni i Hercegovini.

$\mathrm{S}$ druge strane, veće prisustvo tema o euroatlantskim integracijama u online izdanjima dnevnih novina i samostalnih portala može se objasniti privatnim vlasništvom tih medija, na koje vladajuća politika nema tako izražen utjecaj, kao i karakterom samostalnih portala, koji su u suštini alternativni mediji. Osim toga, u odnosu na online izdanja tradicionalnih medija samostalni online portali puno brže i dinamičnije odgovaraju zahtjevima publike, s obzirom da je za njih internet, odnosno interkacija sa publikom, jedini način za pozicioniranje na medijskom tržištu.

Izvještavajući o aktuelnim temama iz domena euroatlantskih integracija, online mediji u Bosni i Hercegovini uglavnom pribjegavaju kraćim novinskim formama, vijestima i izvještajima, što zbog prilagođavanja specifičnim zahtjevima online publike što zbog ograničenih ljudskih i tehničkih resursa. Obimniji, analitički tekstovi o pravu i politici EU-a, ekonomskim trendovima, pravilima za proširenje, ili o specifičnostima organiziranja NATO-a i širenja, još uvijek su rijetkost u online medijima u Bosni i Hercegovini. Također, rijetki su sadržaji online medija koji su proizvod „domaće” produkcije, to jest - čiji su autori novinari online medija u Bosni i Hercegovini. Najčešće možemo konstatovati praksu copy-paste novinarstva, uz minimalne intervencije u skraćivanju jedne ili kombinaciji više različitih izjava već objavljenih na drugim medijima. To je, nažalost, najbolja ilustracija nedovoljnih kompetencija novinara i urednika u vezi s pitanjima politike i prava Europske unije, ali i strateških opredjeljenja NATO-a. Zapravo, nepostojanje edukatora uvjetuje nedovoljnu informativnost, a posebno edukativnost sadržaja online medija u Bosni i Hercegovini spram pitanja euroatlantskih integracija.

Niti jedan od sadržaja online medija koji su bili predmet istraživanja nije 
imao edukativni, već isključivo dnevno-informativni karakter. Edukacijske mogućnosti online medija u Bosni i Hercegovini u vezi s idejom, historijatom, politikom i principima euroatlantskih integracija nisu iskorištene. To je ne samo u suprotnosti s potrebama i očekivanjima publike/korisnika, od kojih se očejuje stav u vezi sa stabilizacijom i pridruživanjem naše zemlje Europskoj uniji i NATO-integracijama već je i u suprotnosti s karaktetom world wide weba kao najvećeg resursa znanja, virtualnom bibliotekom koja se stalno dopunjava.

Domaći online mediji uglavnom zadržavaju neutralan vrijednosni stav o euroatlantskim integracijama, što se može objasniti nespremnošću njihovih redakcija za analitički/istraživački pristup izvještavanju o međunarodnim političkim pitanjima. S tim u vezi je i slaba hiperlinkovska povezanost s drugim izvorima i sadržajima, kao i nizak stupanj interaktivnosti s publikom/ korisnicima online medija.

U skorom vremenu ne možemo očekivati bitnu promjenu odnosa vladajućih partija prema aktuelnim pitanjima euroatlanskih integracija Bosne i Hercegovine niti značajnije pozicioniranje tih tema u javnom/političkom diskursu. S tim u vezi, ne može se očekivati više sadržaja o euro-atlantskim integracijama, posebno originalnih, s potpisom domaćih autora. Kao što je već navedeno, online mediji su suočeni sa specifičnim komunikacijskim okvirima i kruto definisanim navikama publike, dok su, s druge strane, tehnički i kadrovski onemogućeni da se aktivnije uključe u proces edukacije publike o aktuelnim društvenim temama i procesu korištenja online medija na putu ka promjeni komunikacijskih potreba i kreiranju aktivne online javnosti u Bosni i Hercegovini.

Za promjenu odnosa politike i online medija spram tema euroatlantskih integracija bit će potrebna promjena vladajućih etno-nacionalnih politika, jačanje integracijski orijentiranih političkih snaga i pokreta te više znanja o europskim i NATO-integracijama, posebno kadrovsko i profesionalno jačanje online medija u Bosni i Hercegovini. 


\title{
POSSIBILITIES OF BOSNIA AND HERZEGOVINA ONLINE MEDIA IN INFORMATION AND EDUCATION ABOUT EURO- ATLANTIC INTEGRATION
}

\begin{abstract}
- Abstract -
The current political and economic relations in Bosnia and Herzegovina society imply specific approach to media reporting about accession process of Bosnia and Herzegovina to Euro-Atlantic integration, especially to Europian Union and NATO, as specific frames for Bosnian international politics. Defined by internal political conflicts, but also by this year elections, processes of international politics and accession of Bosnia and Herzegovina to Euro-Atlantic integration represent special object of media interest, both traditional and new (online) media. This work primarily describes certain segments of media reports in online media, analyzing fulfillment of basic journalistic standards, abut also specific newmedia characteristics related exclusively for online media, theirs ubiquity, multimediality, speed, adaptability, informativity, educability and interaction with online audience. It is very important to say when we explained some research results, we had in mind level of development in online media in Bosnia and Herzegovina, their human and technical resources, culture of bosnian online communication, but also total current communication situation in Bosnia and Herzegovina.
\end{abstract}

Key words: Online, media, media literacy, self-education, Bosnia and Herzegovina, NATO, European Union, integration.

\section{Literatura}

- Lasić, Mile, Europe Now, Europa sada ili nikada, Kult-B, Depo, Sarajevo, 2011.

- Osmančević, Enes, Demokratičnost $W W W$ komuniciranja, FriedrichEbeert Stiftung, Sarajevo, 2009.

- Tapavički-Duronjić, Tatjana, Kompjuterska kultura i moderni mediji, Filozofski fakultet Banja Luka, 2008.

- Tapavički-Duronjić, Tatjana, Komuniciranje u Medijasferi, Bard-fin, Beograd, Romanov Banja Luka, 2011. 
- Turčilo, Lejla, On-line komunikacija i off-line politika u Bosni $i$ Hercegovini, Internews BiH, Sarajevo, 2006.

- Turčilo, Lejla, Internet i političko komuniciranje u državama u tranziciji: Slučaj Bosna i Hercegovina, Medijska istraživanja br. 1, Zagreb, 2004. 